ISSN 0258-7122

Bangladesh J. Agril. Res. 34(2) : 255-261, June 2009

\title{
EFFECTS OF MAGNESIUM ON THE PERFORMANCE OF POTATO IN THE TISTA MEANDER FLOODPLAIN SOIL
}

\author{
M.A.H. TALUKDER ${ }^{1}$, M.B. ISLAM ${ }^{2}$. S.M.A.H.M. KAMAL ${ }^{3}$ \\ M.A. MANNAF ${ }^{4}$ AND M.M. UDDIN ${ }^{5}$
}

\begin{abstract}
The experiment was conducted in the farmers' field of the Farming Systems Research and Development (FSRD) site, Rangpur under Tista Meander Floodplain highland soils (AEZ \# 3b) for three consecutive Rabi seasons (200203 to 2004-05). The potato variety Cardinal was tested with 5 levels of magnesium viz., $0,5,10,15$, and $20 \mathrm{~kg} / \mathrm{ha}$ to observe its effects on potato and to find out the optimum and economic dose of $\mathrm{Mg}$ for potato. The three years' results revealed that magnesium had significant effects on tuber yield of potato. Significantly higher tuber yield (32.33, 31.63, and $28.03 \mathrm{t} /$ ha in three successive years) was obtained from $10 \mathrm{~kg} / \mathrm{ha}$ of $\mathrm{Mg}$. Tuber yield tended to decrease with increasing rate of $\mathrm{Mg}$ beyond $10 \mathrm{~kg} / \mathrm{ha}$. Tuber yields increased over control by 18 and 31 \% when magnesium was applied @ 5 and 10 kg/ha, respectively. Yield response to added $\mathrm{Mg}$ was quadratic in nature. The regression with $\mathrm{Mg}$ levels indicate that maximum tuber yield (30.32 t/ha) could be obtained at 13 $\mathrm{kg} / \mathrm{ha}$ of $\mathrm{Mg}$ and the economic dose was also $13 \mathrm{~kg} / \mathrm{ha}$ of $\mathrm{Mg}$. Use efficiency of $\mathrm{Mg}$ was $512.25 \mathrm{~kg}$ tuber of potato per $\mathrm{kg} \mathrm{Mg}$ per ha. After optimum level of Mg (13 kg/ha) tuber yield reduced by $3.83 \mathrm{~kg}$ for additional use of one $\mathrm{kg} \mathrm{Mg} / \mathrm{ha}$.
\end{abstract}

Key Words: Potato, tuber yield, magnesium, use efficiency.

\section{Introduction}

Potato (Solanum tuberosum L.) is one of the major vegetables grown during winter season and commercially cultivated in the FSRD site, Syedpur. One of the most important constrains of higher tuber yield is the lack of adequate balanced fertilizer application. Since 1980, farmers were using only NPK-fertilizers, but now they are applying S and Zn along with NPK. Deficiencies of Mg in some soils and crops (potato, maize, and tomato) were found in the northern districts, especially in Rangpur and Dinajpur (Jahiruddin et al., 1992 and Islam et al., 1992). Plants are deficit to $\mathrm{Mg}$ in the soil having low $\mathrm{pH}$, sandy in nature and highly leached soil with low Cation Exchange Capacity (Tisdale et al., 1990). Magnesium deficiencies are most frequently found in the region of heavy rainfall and in light textured soils of northern district (Anonymous, 1988). The most common symptom of $\mathrm{Mg}$ deficiency was observed in the potato field is plants showed interveinal chlorosis on the older leaves. Magnesium is an important

${ }^{1}$ Horticulture Research Centre, BARI, Gazipur, ${ }^{2}$ On-Farm Research Division, BARI, Gazipur, ${ }^{3 \& 4}$ On-Farm Research Division, BARI, Rangpur, ${ }^{5}$ Regional Agricultural Research Station, Rahmatpur, Barisal, Bangladesh. 
constituent of chlorophyll molecule, therefore, essential for photosynthesis. Magnesium increase NPK uptake and thereby increase yield (Kene et al., 1990) and promotes uptake and translocation of phosphorus (Russell, 1975). Soil in the experimental fields are sandy loam and acidic in nature. Magnesium content in this soil is low to medium (0.71-0.82 meq/100 g soil). Besides, the information regarding optimum dose of $\mathrm{Mg}$ for potato is very scanty. Therefore, the present investigation was undertaken to find out the optimum and economic dose of $\mathrm{Mg}$ as well as its use efficiency for potato production in Tista Meander Floodplain Soil.

\section{Materials and method}

The experiment was conducted at the Farming Systems Research and Development (FSRD) Site. Syedpur in the farmer's field under Tista Meander Floodplain highland soils (AEZ \# 3b) for three consecutive Rabi seasons (200203 to 2004-05). The potato variety Cardinal was used. Five levels of Mg viz., 0, $5,10,15$, and $20 \mathrm{~kg} / \mathrm{ha}$ were considered as the treatments. The trial was conducted in randomized complete block design with 6 dispersed replications. Soil samples were collected for laboratory analysis and the results are represented in Table 1.

Table 1. Initial soil status of the experimental plots of potato.

\begin{tabular}{|c|c|c|c|c|c|c|c|c|c|}
\hline \multirow[t]{2}{*}{ Year } & \multirow[t]{2}{*}{$\mathrm{pH}$} & \multirow{2}{*}{\begin{tabular}{|l} 
Total N \\
(\%)
\end{tabular}} & \multirow{2}{*}{\begin{tabular}{|l}
$\mathrm{OM}$ \\
$(\%)$
\end{tabular}} & \multicolumn{3}{|c|}{ meq/100g soil } & \multicolumn{3}{|c|}{$\mu g / g$ soil } \\
\hline & & & & $\mathrm{Ca}$ & $\mathrm{Mg}$ & K & $\mathrm{P}$ & S & $\mathrm{Zn}$ \\
\hline $\begin{array}{l}2002-03 \\
\text { (Year 1) }\end{array}$ & 5.37 & 0.11 & 2.17 & 2.4 & 0.82 & 0.32 & 28.9 & 13 & 0.55 \\
\hline $\begin{array}{l}\text { 2003-04 } \\
\text { (Year 2) }\end{array}$ & 5.10 & 0.08 & 1.89 & 2.1 & 0.71 & 0.29 & 17.2 & 10 & 0.60 \\
\hline $\begin{array}{l}\text { 2004-05 } \\
\text { (Year 3) }\end{array}$ & 5.66 & 0.10 & 2.00 & 1.9 & 0.73 & 0.44 & 22.4 & 14 & 0.49 \\
\hline Critical level & - & 0.12 & - & 2 & 0.50 & 0.12 & 10.0 & 10 & 0.6 \\
\hline
\end{tabular}

The unit plot size was $5 \mathrm{~m} \mathrm{x} 3 \mathrm{~m}$. The potato tubers of 28-35 $\mathrm{mm}$ in diameter were sown during 2-3 December 2002 (Year 1), 5-7 December 2003 (Year 2), and 3-5 December 2004 (Year 3) with a spacing of $60 \mathrm{~cm} \times 25 \mathrm{~cm}$. The entire plot was fertilized with a blanket dose of 125-10- 40-14-3.5-7500 kg N-P-K-S-Zncowdung per hectare in the year I and 140-17-40-16-3.3-7500 and 130-11-40-133.8-7500 kg N-P-K-S-Zn-cowdung per hectare in year 2 and 3, respectively. Urea, triple super phosphate (TSP), muriate of potash (MoP), magnesium sulphate, gypsum and zinc sulphate were used as a sources of $\mathrm{N}, \mathrm{P}, \mathrm{K}, \mathrm{Mg}, \mathrm{S}$ and Zn, respectively. The amount of S supplied through different sources was noted and the remaining amount of S was applied as gypsum. Doses were calculated 
according to Fertilizer Recommendation Guide'97 based on soil initial nutrient status (Anonymous, 1997). The entire quantity of well-decomposed cowdung was applied during land preparation. Just after planting of potato tuber, furrows were made near both the sides of potato line with $5-6 \mathrm{~cm}$ depths from the soil surface. The entire quantity of TSP, MP, gypsum, zinc sulphate, and half amount of urea were applied in these furrows and immediately the furrows were covered with soil. Magnesium as magnesium sulphate also applied in these furrows as per treatments. The remaining urea was applied as side dress during earthing up at 42-45 days after planting.

Two to three irrigations were given depending on visual soil moisture condition. In l year, two irrigations were applied at 10 and 25 days after planting and in 2 and 3 year, it was applied three times at 25, 40, and 60 days after planting. Ridomil and Malatap were applied as preventive measure against late blight and leaf viruses. Potato tubers were harvested $1^{\text {st }}$ week to $2^{\text {nd }}$ week of March in each year. Data on the yield and yield contributing characters were recorded from ten randomly selected plants of each unit plot and analyzed statistically and the mean separation was done following Duncan's Multiple Range Test (Gomez and Gomez, 1984). Regression analysis from mean tuber yields with $\mathrm{Mg}$ levels was done to fit in the quadrant function. The optimum dose of $\mathrm{Mg}$ was calculated using the formula $\mathrm{Y}=\mathrm{b} / 2 \mathrm{c}$ from the response curve based on economic dose and economic yields.

\section{Results and Discussion}

The results presented in Table 2 and 3 reveal that there was significant difference among the treatments in respect of tuber weight per hill, which might have increased tuber yield significantly. But plant height, shoots per hill as well as number of tubers per hill did not differ significantly. Tuber weight per hill increased significantly with the increasing rate of $\mathrm{Mg}$ upto $10 \mathrm{~kg} / \mathrm{ha}$ in all tested years and beyond that slightly increased or decreased.

Tuber yield increased significantly with increasing rate of Mg upto $10 \mathrm{~kg} / \mathrm{ha}$. Higher tuber yield was obtained $(32.33,31.63$, and $28.03 \mathrm{t} / \mathrm{ha}$ during three successive years) with $10 \mathrm{~kg} / \mathrm{ha}$ of $\mathrm{Mg}$ that was statistically identical to the yields obtained with 15 and $20 \mathrm{~kg} / \mathrm{ha}$ of Mg. Russell (1975) reported that Mg plays an important role in the transportation of phosphate in the plant leading to higher yield. Tuber yield tended to decrease with increasing rate of $\mathrm{Mg}$ beyond 10 $\mathrm{kg} / \mathrm{ha}$. Significantly the lowest yield was obtained from untreated control plot. Average tuber yield of potato was increased by 18 and $31 \%$ from 5 and $10 \mathrm{~kg} / \mathrm{ha}$ of $\mathrm{Mg}$, respectively, over untreated control. Magnesium at the rate of $10 \mathrm{~kg} / \mathrm{ha}$ increased 31\% mean tuber yield over magnesium control. The result is in agreement with the findings reported by Kumari et al. (1999). 
Plants in the plot without $\mathrm{Mg}$ (control plot) was observed interveinal chlorosis of older leaves followed by necrosis in each year followed by that of plots treated with $5 \mathrm{~kg} \mathrm{Mg}$ per hectare and the plants in the plot treated with 10 $\mathrm{kg} \mathrm{Mg}$ per hectare Mg deficiency symptom were seen sporadically. Plants in the plot treated with 15 and $20 \mathrm{~kg}$ Mg per hectare remain green.

Table 2. Effects of different levels of $\mathrm{Mg}$ on the yield attributes of potato at Rangpur during 2002-03 to 2004-05.

\begin{tabular}{|c|c|c|c|c|}
\hline Mg level (kg/ha) & $\begin{array}{l}\text { Plant height } \\
(\mathrm{cm})\end{array}$ & Shoots/hill (no.) & Tubers/hill (no.) & $\begin{array}{l}\text { Tuber wt./hill } \\
\text { (g) }\end{array}$ \\
\hline \multicolumn{5}{|c|}{ Year 1} \\
\hline 0 & 77.8 & 3.6 & 10.4 & $420 \mathrm{c}$ \\
\hline 5 & 81.1 & 3.6 & 10.8 & $479 \mathrm{~b}$ \\
\hline 10 & 78.6 & 3.8 & 11.0 & 530 a \\
\hline 15 & 79.2 & 3.7 & 10.8 & $505 \mathrm{ab}$ \\
\hline 20 & 80.4 & 3.8 & 10.5 & $499 \mathrm{ab}$ \\
\hline CV (\%) & 6.2 & 6.8 & 6.6 & 5.9 \\
\hline \multicolumn{5}{|c|}{ Year 2} \\
\hline 0 & 79.3 & 3.6 & 9.6 & $406 \mathrm{c}$ \\
\hline 5 & 81.3 & 3.6 & 10.2 & $452 \mathrm{~b}$ \\
\hline 10 & 79.2 & 3.7 & 10.7 & 508 a \\
\hline 15 & 82.4 & 3.8 & 9.9 & $488 \mathrm{ab}$ \\
\hline 20 & 79.8 & 3.8 & 10.1 & $486 \mathrm{ab}$ \\
\hline CV (\%) & 7.6 & 7.5 & 5.9 & 6.1 \\
\hline \multicolumn{5}{|c|}{ Year 3} \\
\hline 0 & 79.8 & 3.7 & 9.6 & $363 \mathrm{~d}$ \\
\hline 5 & 80.6 & 3.8 & 10.4 & $415 \mathrm{c}$ \\
\hline 10 & 79.9 & 3.6 & 10.9 & 468 a \\
\hline 15 & 83.2 & 3.7 & 9.8 & 449 a \\
\hline 20 & 81.4 & 3.9 & 10.0 & 426 bc \\
\hline CV (\%) & 6.0 & 7.9 & 6.3 & 6.3 \\
\hline
\end{tabular}

Monthly average rainfall and daily temperature are shown in Appendix 1. During the year I, no rainfall was occurred in the month of December and 6.6, 23.1, and $109.2 \mathrm{~mm}$ rainfall was received during January, February, and March, respectively. No rainfall received in the month of February and uniform rainfall was occurred from December to March (24, 8.1, and $39 \mathrm{~mm}$, respectively) in the year 2 . During year 3, uniform rainfall was received from January to March. But in December, it was only $3.2 \mathrm{~mm}$. This year, $9 \mathrm{~mm}$ rainfall with hailstorm 
occurred just after $3^{\text {rd }}$ irrigation which might have adversely affected tuber yield compared to that of year I and year 2 . Average of daily maximum temperature in the year I was lower in January $\left(19.87^{\circ} \mathrm{C}\right)$ compared to the year 2 and year 3 and minimum temperature was also lower in January in each year. The maximum and minimum temperatures prevailed higher in the month of March in each year. Beside these, daily average maximum and minimum temperature do not vary markedly.

Table 3. Effects of different levels of $\mathrm{Mg}$ on the yield of potato at Rangpur during 2002-03 to 2004-05.

\begin{tabular}{l|l|l|l|l|l}
\hline \multirow{2}{*}{$\begin{array}{c}\text { Mg level } \\
\text { (kg/ha) }\end{array}$} & \multicolumn{5}{c}{ Tuber yield (t/ha) } \\
\cline { 2 - 6 } & Year 1 & Year 2 & Year 3 & Mean & $\begin{array}{c}\text { \% Increase } \\
\text { over control }\end{array}$ \\
\hline 0 & $25.33 \mathrm{c}$ & $24.20 \mathrm{c}$ & $20.60 \mathrm{c}$ & 23.38 & - \\
5 & $29.55 \mathrm{~b}$ & $28.31 \mathrm{~b}$ & $24.91 \mathrm{~b}$ & 27.59 & 18 \\
10 & $32.33 \mathrm{a}$ & $31.63 \mathrm{a}$ & $28.03 \mathrm{a}$ & 30.66 & 31 \\
15 & $30.95 \mathrm{ab}$ & $30.26 \mathrm{ab}$ & $26.56 \mathrm{ab}$ & 29.26 & 25 \\
20 & $30.75 \mathrm{ab}$ & $30.07 \mathrm{ab}$ & $26.17 \mathrm{ab}$ & 29.00 & 24 \\
\hline CV (\%) & 6.2 & 8.6 & 8.3 & - & - \\
\hline
\end{tabular}

Means followed by the same letter (s) in a column are not significantly different at $5 \%$ level by DMRT.

Quadratic relation derived from three years' average tuber yield with $\mathrm{Mg}$ levels has been shown in Fig. 1. From the regression equation derived from the response curve of mean tuber yield of potato with Mg levels, it was observed that maximum tuber yield (30.32 t/ha) could be achieved when $13 \mathrm{~kg} / \mathrm{ha}$ of $\mathrm{Mg}$ was applied. The economic dose of Mg was also $13 \mathrm{~kg} / \mathrm{ha}$. At the optimum level (13 $\mathrm{kg} / \mathrm{ha}$ ), magnesium use efficiency was $512.25 \mathrm{~kg}$ tuber of potato per ha per $\mathrm{kg}$ of Mg (Table 4). After the optimum level of Mg, tuber yield was found to be reduced by $3.83 \mathrm{~kg}$ for additional use of one $\mathrm{kg}$ magnesium per ha.

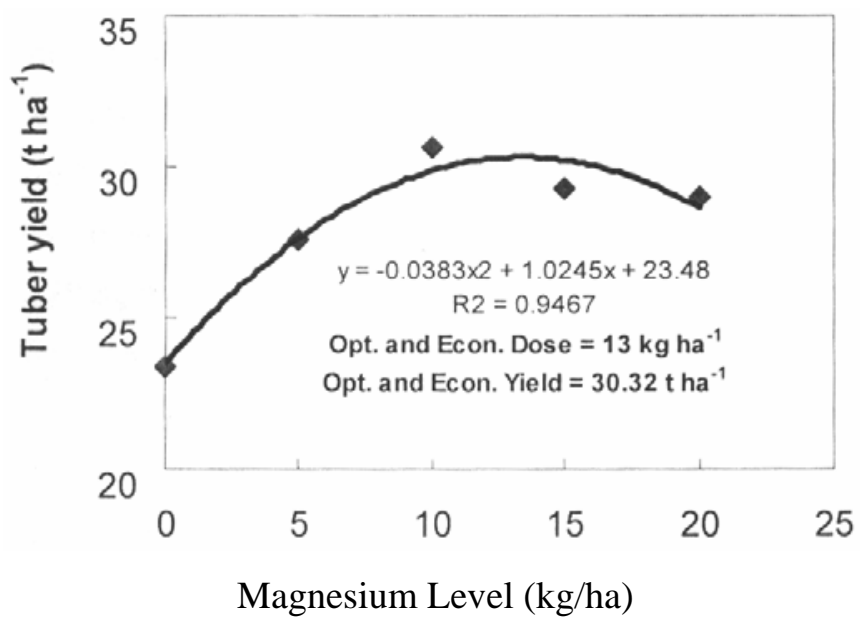

Fig. 1. Response of tuber yield of potato to added Magnesium (average of three years). 
Table 4. Response function for tuber yield of potato.

\begin{tabular}{|c|c|c|c|c|c|}
\hline \multirow[t]{2}{*}{$\mathrm{R}^{2}$ value } & \multirow[t]{2}{*}{$\begin{array}{l}\text { Regression } \\
\text { equation }\end{array}$} & $\begin{array}{c}\text { Rate of Mg } \\
\text { (kg/ha) }\end{array}$ & $\begin{array}{c}\text { Tuber yield } \\
\text { (t/ha) }\end{array}$ & \multirow{2}{*}{$\begin{array}{l}\text { Tuber yield } \\
\text { production/ } \\
\text { kg of } \mathrm{Mg} / \mathrm{ha} \\
\text { (MUE) (kg) }\end{array}$} & \multirow{2}{*}{$\begin{array}{c}\text { Tuber yield } \\
\text { reduction/kg } \\
\text { of } \mathrm{Mg} / \mathrm{ha} \\
\text { above } \\
\text { optimum rate } \\
\text { (kg) }\end{array}$} \\
\hline & & $\begin{array}{l}\text { Optimum/ } \\
\text { Economic }\end{array}$ & $\begin{array}{l}\text { Optimum/ } \\
\text { Economic }\end{array}$ & & \\
\hline 0.95 & $\begin{array}{c}Y=-0.00383 \mathrm{x}^{2} \\
+1.0245 \mathrm{x}+ \\
23.48\end{array}$ & 13 & 30.32 & 512.25 & 3.83 \\
\hline
\end{tabular}

MUE= Magnesium Use Efficiency.

\section{Farmers' Reaction}

Farmers' express their willingness to apply Mg with other fertilizer in the coming season ftr potato cultivation.

\section{Conclusion}

From the results, it may be concluded that $13 \mathrm{~kg} / \mathrm{ha} \mathrm{Mg}$ may be optimum for boosting potato production in the Tista Meander Floodplain soil.

\section{Acknowledgement}

The piece of research was part of the project 'Soil Fertility and Fertilizer Management Project (SFFP)" funded by Danish International Development Agency (DANIDA), Denmark.

\section{References}

Anonymous. 1988. On-Farm Research Division, BARI, Joydebpur, Gazipur

Anonymous. 1997. Fertilizer Recommendation Guide 1997. Bangladesh Agricultural Research Council, Farmgate, Dhaka-1215. P45

Bear, F. F. 1965. Soils in Relation to Crop Growth, NewYork, Reinhold Publishing Corporation, Chapman \& Hall Ltd., London. p. 207

Gomez, A.K. and A.A. Gomez. 1984. Statistical Procedure for Agricultural Research, second edition, John Wiley and Sons, pp 95-109

Islam, A. 1992, Review of Soil Fertility Research in Bangladesh. Proc. Inter-Congr. Conf., Commission IV, ISSS on Improving Soil Management for Intensive Cropping in the Tropics and Sub-Tropics, pp 1-18

Islam, M.S., M.S. Arnin and M.N. Anwar. 1992. Review of Soil Fertility Research in Bangladesh. Proc. Inter-Congr. Conf., Commission IV, ISSS on Improving Soil Management for Intensive Cropping in the Tropics and Sub-Tropics, pp 147-156

Jahiruddin, M., M.S. Hoque, A.K.M.M. Haque and P.K. Roy. 1992. Influence of boron, copper and molybdenum on grain formation in wheat. Crop Res. 5: 3 5-42 
Kene, H.K., ST. Wankhade and B.N. Sagare. 1990. Influence of nutrient spray on yield and oil content of snflower. Annals Plant Physiol. 4(2): 249-251

Kumari K. M., B.M. Sharma,, R.K. Sharma and S.S. Balloli. 1999. Effect of phosphorusmagnesium interaction on yield and oil content of mustard. J. Indian Soc. Soil Sci. 47(2): $379-380$

Nur-E-Elahi, M. F. Hlaque and C.A. Meisner. 2002. Bhutta Utpadon, Paribarik Proshikhan (In Bangla $2^{\text {nd }}$ Ed.). Pub. by the International Wheat and Maize Improvement Centre (CIMMYT), House no. 18, Road no. 4, Sector no. 4, Uttara Model Town, Uttara, Dhaka-1230, pp 7-11

Russell, E.W. 1975. Soil conditions and plant growth. $10^{\text {th }}$ Ed., Great Britain, William Clowes \& Sons Ltd., London. ELBS, p. 43

Tisdale, S. F, W. L. Nelson and J. D. Beaton. 1990. Soil fertility and fertilizers. $4^{\text {th }}$ Ed.. Macmillan Publishing Company, New York, p.335

Appendix 1. Mean monthly temperature and rainfall data at Rangpur during experimental period.

\begin{tabular}{|c|c|c|c|c|c|c|c|c|c|}
\hline \multirow[t]{3}{*}{ Month } & \multicolumn{6}{|c|}{ Temperature $\left({ }^{0} \mathrm{C}\right)$} & \multirow{2}{*}{\multicolumn{3}{|c|}{ Total rainfall (mm) }} \\
\hline & \multicolumn{2}{|c|}{ 2002-03 } & \multicolumn{2}{|c|}{ 2003-04 } & \multicolumn{2}{|c|}{ 2004-05 } & & & \\
\hline & Max & Min & Max & Min & Max & Min & 2002-03 & 2003-04 & 2004-05 \\
\hline November & 28.64 & 18.14 & 28.68 & 17.68 & 28.63 & 17.03 & 14.4 & 0 & 0 \\
\hline December & 24.97 & 14.14 & 26.52 & 14.46 & 25.95 & 14.05 & 0 & 24.0 & 3.2 \\
\hline January & 19.87 & 9.27 & 22.04 & 11.66 & 23.85 & 11.78 & 6.6 & 8.1 & 11.5 \\
\hline February & 25.69 & 14.23 & 26.74 & 14.39 & 22.50 & 12,70 & 23.1 & 0 & 10.9 \\
\hline March & 28.22 & 17.23 & 28.66 & 19.37 & 30.74 & 21.74 & 109.2 & 39.0 & 70.6 \\
\hline
\end{tabular}

